\title{
An Investigation on Kinetics of Photo Catalysis, Characterization, Antibacterial and Antimitotic Property of Electrochemically Synthesized ZnS and $\mathrm{ZrS}_{2} / \mathrm{ZnS}$ Nano Photocatalysts
}

\author{
Hosaholalu Balakrishna Uma1, Sannaiah Ananda1 ${ }^{*}$, Vittal Ravishankar Rai², \\ Kiana Alasvand Zarasvand ${ }^{2}$ \\ ${ }^{1}$ Department of Studies in Chemistry, University of Mysore, Mysuru, India \\ ${ }^{2}$ Department of Studies in Microbiology, University of Mysore, Mysuru, India \\ Email: umapriyahb2015@gmail.com, ^snananda@yahoo.com,raivittal@gmail.com, kianaalasvand@gmail.com
}

How to cite this paper: Uma, H.B., Ananda, S., Rai, V.R. and Zarasvand, K.A. (2017) An Investigation on Kinetics of Photo Catalysis, Characterization, Antibacterial and Antimitotic Property of Electrochemically Synthesized $\mathrm{ZnS}$ and $\mathrm{ZrS}_{2} / \mathrm{ZnS}$ Nano Photocatalysts. Modern Research in Catalysis, 6, 30-46.

http://dx.doi.org/10.4236/mrc.2017.61003

Received: October 9, 2016

Accepted: January 19, 2017

Published: January 22, 2017

Copyright ( $) 2017$ by authors and Scientific Research Publishing Inc. This work is licensed under the Creative Commons Attribution International License (CC BY 4.0).

http://creativecommons.org/licenses/by/4.0/

c) (i) Open Access

\begin{abstract}
Zinc sulphide is one of the commercially important II-VI semiconductors having a wide band gap, rendering it a very attractive material for optical application especially in nanocrystalline form. Nanocomposites of $\mathrm{ZnS}$ and $\mathrm{ZrS}_{2} / \mathrm{ZnS}$ were prepared by simple electrochemical method; their photocatalytic properties had been investigated. The structure, composition and optical property of the product were characterized by X-ray diffraction (XRD), FESEM (EDAX), UV-VIS and IR techniques. The UV-VIS spectra exhibited a blue-shift with respect to that of bulk material due to quantum confinement effect. Kinetics of photocatalytic degradation of Indigo Carmine dye has been studied. The photocatalytic decolourization of the dye follows first order kinetics. The antimitotic and antibacterial activity of these nanoparticles was investigated.
\end{abstract}

\section{Keywords}

Electrochemical Synthesis, Bioluminescence, Photobacterium leiognathi, Allium cepa

\section{Introduction}

Over the past few decades, environmental problems associated with harmful organic pollutants in waste water are driving force for sustained fundamental and applied research in the area of environmental remediation [1]. Semiconductorassisted photo catalysis has received considerable attention as a promising tool 
for implementing the purification of waste water and hydrogen energy production [2]. Last two decades have witnessed a rapid advancement in various techniques for the fabrication of nanoparticles [3] [4]. Among the various semiconducting materials, $\mathrm{ZnS}$ is a wide-band gap semiconductor of $3.8 \mathrm{eV}$ having luminescent properties and photocatalytic applications. ZnS is one of the II-VI semiconducting material finding application in Cathode ray tubes, IR windows, injection lasers, ultraviolet light-emitting diodes and flat panel displays [5] [6]. Doping of metal ions into $\mathrm{ZnS}$ can influence the performance of these photocatalysts. $\mathrm{ZnS}$ has been extensively studied with the aim of controlling the size, morphology and crystallinity in order to obtain desired physical properties [7] [8]. Many methods have been used to synthesize ZnS nanoparticles such as sol-gel, hydrothermal, solvothermal and mechanochemical methods. $\mathrm{ZnS}$ obtained by this techniques has a wide band gap of $4-4.6 \mathrm{eV}$ [9]. An electrochemical procedure based on the dissolution of a metallic anode in a protic solvent, has been used to obtain nanoparticles ranging from 10 to $20 \mathrm{~nm}$ with reduced band gap [10] [11].

$\mathrm{Zr}$ is a transition metal mainly used as refractory and opacifier and in small amount as an alloying agent for its strong resistance to corrosion. Zirconium containing compounds are used in many biomedical applications, including dental implants and other restorative practices, knee and hip replacements, although $\mathrm{Zr}$ has no known biological role [12] [13] [14]. However, a few papers have been reported on photocatalytic and biological applications of Zirconium doped nanoparticles. Doping of $\mathrm{Zr}$ to $\mathrm{ZnS}$ is quite attractive, since the dissolution potential of $\mathrm{Zr}(-1.45 \mathrm{eV})$ is more negative than $\mathrm{Zn}(-0.7618 \mathrm{eV})$ and also the radius of $\mathrm{Zr}^{4+}(0.86 \AA)$ is almost similar to that of $\mathrm{Zn}^{2+}(0.88 \AA)$. Keeping in view, $\mathrm{ZnS}$ and $\mathrm{ZrS}_{2} / \mathrm{ZnS}$ nanocomposites were fabricated by the novel electrochemical method and their catalytic effects on photodegradation of Indigo carmine dye and antibacterial activity using Gram negative bioluminescent Photobacterium leiognathi and antimitotic activity using Allium cepa have been reported here.

\section{Experimental}

\subsection{Synthesis of ZnS Nanoparticles}

Zinc Sulphide nanoparticles are synthesized electrochemically using Zinc and platinum electrodes as shown in Figure 1. The electrolytic cell consisting of 0.5

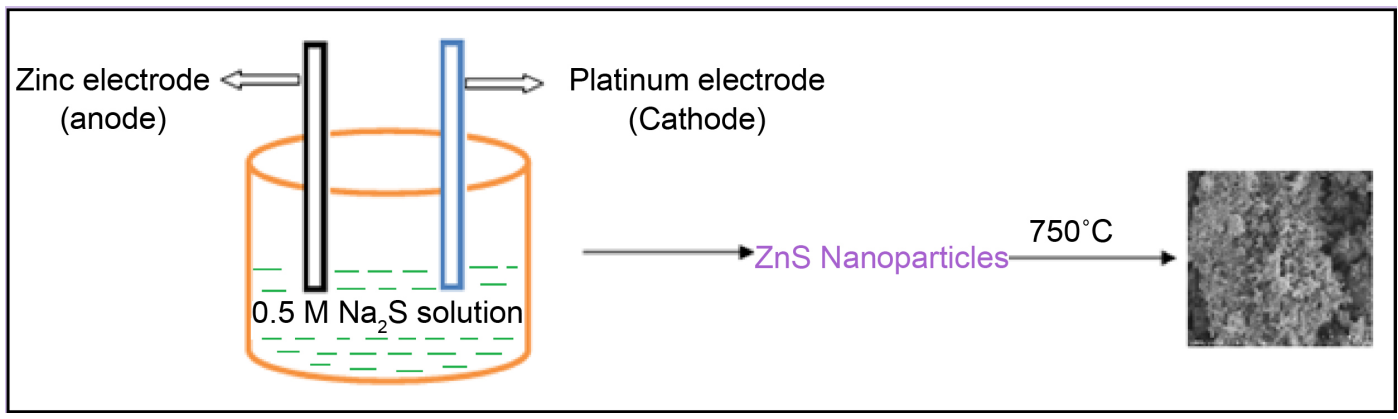

Figure 1. Diagrammatic representation of electrochemical formation of $\mathrm{ZnS}$ nanoparticles. 
$\mathrm{M}$ aqueous $\mathrm{Na}_{2} \mathrm{~S}$ solution and electrodes are separated by $1 \mathrm{~cm}$. The experiment was run for $3 \mathrm{hrs}$ with continuous stirring using $30 \mathrm{~mA}$ current and a potential of $20 \mathrm{~V}$. During the electrolysis Zinc electrode acts as anode starts to dissolve and gives Zinc ions which are electrochemically reacted with sulphide ions furnished by $\mathrm{Na}_{2} \mathrm{~S}$ to give $\mathrm{ZnS}$ nanoparticles. The obtained nanoparticles are washed repeatedly with distilled water till complete removal of Sodium Sulphide, centrifuged and calcinated at $750^{\circ} \mathrm{C}$ for $2 \mathrm{hrs}$ to remove Sodium and hydroxide impurities.

\subsection{Synthesis of $\mathrm{ZrS}_{2} / \mathrm{ZnS}$ Nanoparticles}

The experimental set up is similar to synthesis of ZnS. Here Zinc, platinum and Zirconium electrodes were used. The rate of electrochemical reaction is not same for $\mathrm{Zr}^{4+}$ and $\mathrm{Zn}^{2+}$, as the redox potential of $\mathrm{Zr}^{4+}$ and $\mathrm{Zn}^{2+}$ are different. Since the dissolution potential of $\mathrm{Zr}(-1.45 \mathrm{eV})$ is more negative than $\mathrm{Zn}(-0.7618 \mathrm{eV})$, formation of $\mathrm{ZrS}_{2}$ takes place in competition with $\mathrm{ZnS}$. The mechanism of electrochemical formation is as follows:

$$
\begin{aligned}
\mathrm{Zn} & \rightleftharpoons \mathrm{Zn}^{2+}+2 e^{-} \\
\mathrm{Na}_{2} \mathrm{~S} & \rightarrow 2 \mathrm{Na}^{+}+\mathrm{S}^{2-} \\
2 \mathrm{Na}^{+}+2 e^{-} & \rightarrow 2 \mathrm{Na}\left(\text { at } \mathrm{Pt} e^{-} d e\right) \\
\mathrm{Zn}^{2+}+\mathrm{S}^{2-} & \rightleftharpoons \mathrm{ZnS} \\
\mathrm{Zr}^{4+}+2 \mathrm{~S}^{2-} & \rightleftharpoons \mathrm{ZrS}_{2}
\end{aligned}
$$

Scheme 1. Mechanism of electrochemical formation of $\mathrm{ZrS}_{2} / \mathrm{ZnS}$ nanocomposite.

\subsection{Determination of Photocatalytic Activities}

The photo reactivity of nanocatalysts are influenced by variables such as the dopant, $\mathrm{pH}$ of solution, dosage of photo catalyst, concentration of dye and exposure to different source of light viz., sunlight and UV light [15] [16]. Indigo carmine dye (Molecular formula: $\mathrm{C}_{16} \mathrm{H}_{8} \mathrm{O}_{8} \mathrm{~N}_{2} \mathrm{~S}_{2}$, Molecular weight: $466.16, \lambda_{\max }=$ $610 \mathrm{~nm}$ ) solution was prepared by dissolving in distilled water. This solution was used as test contaminant for evaluating photocatalytic activities. To assess the photocatalytic efficiency of the prepared nanoparticles, photodegradation experiments were carried out using different concentration of Indigo carmine dye as substrate and different concentrations of $\mathrm{ZnS}$ and $\mathrm{ZrS}_{2} / \mathrm{ZnS}$ as catalyst. A calculated amount of catalyst was added to the dye solution, stirred in dark for 1 min to establish adsorption/ desorption equilibrium between dye and nanoparticles and then illuminated under $8 \mathrm{~W}$ UV source to induce a photoche- mical reaction. Aliquots were taken at an interval of $2 \mathrm{~min}$ (in case of $\mathrm{ZnS}$ ) and $10 / 15 \mathrm{~min}$ (in case of $\mathrm{ZrS}_{2} / \mathrm{ZnS}$ ) and percent transmittance was determined.

The adsorption and photocatalytic conversion ( $\mathrm{g} \%$ ) was calculated as follows [17]: 


$$
\mathrm{COD}=\frac{8000(\text { vol of FAS in blank }- \text { vol of FAS in dye soln }) \text { normality of FAS }}{\text { Sample volume }} .
$$

The mineralization of dye was measured by the decrease of chemical oxygen demand (COD) of the solution. The COD was measured according to the standard dichromate titration method [18] [19]. The mineralization efficiency of dye was estimated by the following expression:

$$
\% \text { efficiency }=\frac{\text { Initial COD }- \text { Final COD }}{\text { Initial COD }} \times 100 .
$$

The decrease in COD (mg/l) and increase in \% Tof the dye solution with colour removal was observed as follows:

$\mathrm{ZnS}$ nanoparticles $>\mathrm{ZrS}_{2} / \mathrm{ZnS}$ nanoparticles .

The mechanism of photodegradation can be represented as follows [20] [21].

$$
\begin{aligned}
\mathrm{Np}+h v & \rightarrow e^{-}+h^{+} \\
h^{+}+\mathrm{H}_{2} \mathrm{O} & \rightarrow \mathrm{OH} \cdot+h^{+} \\
h^{+}+\mathrm{OH}^{-} & \rightarrow \mathrm{OH} \cdot \\
e^{-}+\mathrm{O}_{2} & \rightarrow \mathrm{O}_{2}^{-} \\
\mathrm{O}_{2}^{-}+\mathrm{H}_{2} \mathrm{O} & \rightarrow \mathrm{HO}_{2}^{-}+\mathrm{OH} \cdot \\
\mathrm{HO}_{2}^{-}+\mathrm{H}_{2} \mathrm{O} & \rightarrow \mathrm{OH} \cdot+\mathrm{H}_{2} \mathrm{O} \\
\mathrm{H}_{2} \mathrm{O}_{2} & \rightarrow 2 \mathrm{OH} \cdot \\
\mathrm{OH} \cdot+\mathrm{IC} & \rightarrow \text { Intermediate products } \\
& \rightarrow \text { Degradation products } \\
\mathrm{O}_{2}^{-}+\mathrm{IC} & \rightarrow \text { Intermediate products } \\
& \rightarrow \mathrm{CO}_{2}, \mathrm{H}_{2} \mathrm{O}, \mathrm{NH}_{3} \text { and other degradation products }
\end{aligned}
$$

Scheme 2. Mechanism of dye degradation by $\mathrm{OH}$ radical.

\section{Results and Discussion}

\subsection{X-Ray Diffraction}

The XRD pattern of synthesized $\mathrm{ZnS}$ and $\mathrm{ZrS}_{2} / \mathrm{ZnS}$ nanoparticles are shown in Figure 2. The XRD for $\mathrm{ZnS}$ shows three main diffraction peaks at $2 \theta$ values $31.61,34.28$ and 36.08. The obtained peak positions correspond to Zinc blended type patterns and the XRD pattern is well matched with standard cubic ZnS [6]. The XRD of $\mathrm{ZrS}_{2} / \mathrm{ZnS}$ nanoparticles are compared with $\mathrm{ZnS}$ nanoparticles and are as follows. From the XRD data it is evident that no much change in the position of diffraction peaks were observed compared to $\mathrm{ZnS}$ nanoparticles. A possible reason could be that $\mathrm{Zr}^{4+}$ entered into the crystal lattice of $\mathrm{ZnS}$ and suppress the growth of $\mathrm{ZnS}$ crystals, because radius of $\mathrm{Zr}^{4+}(0.86 \AA)$ smaller than that of $\mathrm{Zn}^{2+}(0.88 \AA)$ and $\mathrm{Zr}$ substitutes $\mathrm{Zn}$ in the lattice. The slight change of lattice parameters of $\mathrm{ZrS}_{2} / \mathrm{ZnS}$ also proved that the $\mathrm{Zr}$ ions were incorporated into the $\mathrm{ZnS}$ lattice.

From the XRD data the cell parameters are calculated for ZnS nanoparticles and it is found to be $a=b \neq c(a=8.483 \AA, b=8.483 \AA$ and $c=9.957 \AA)$ and 

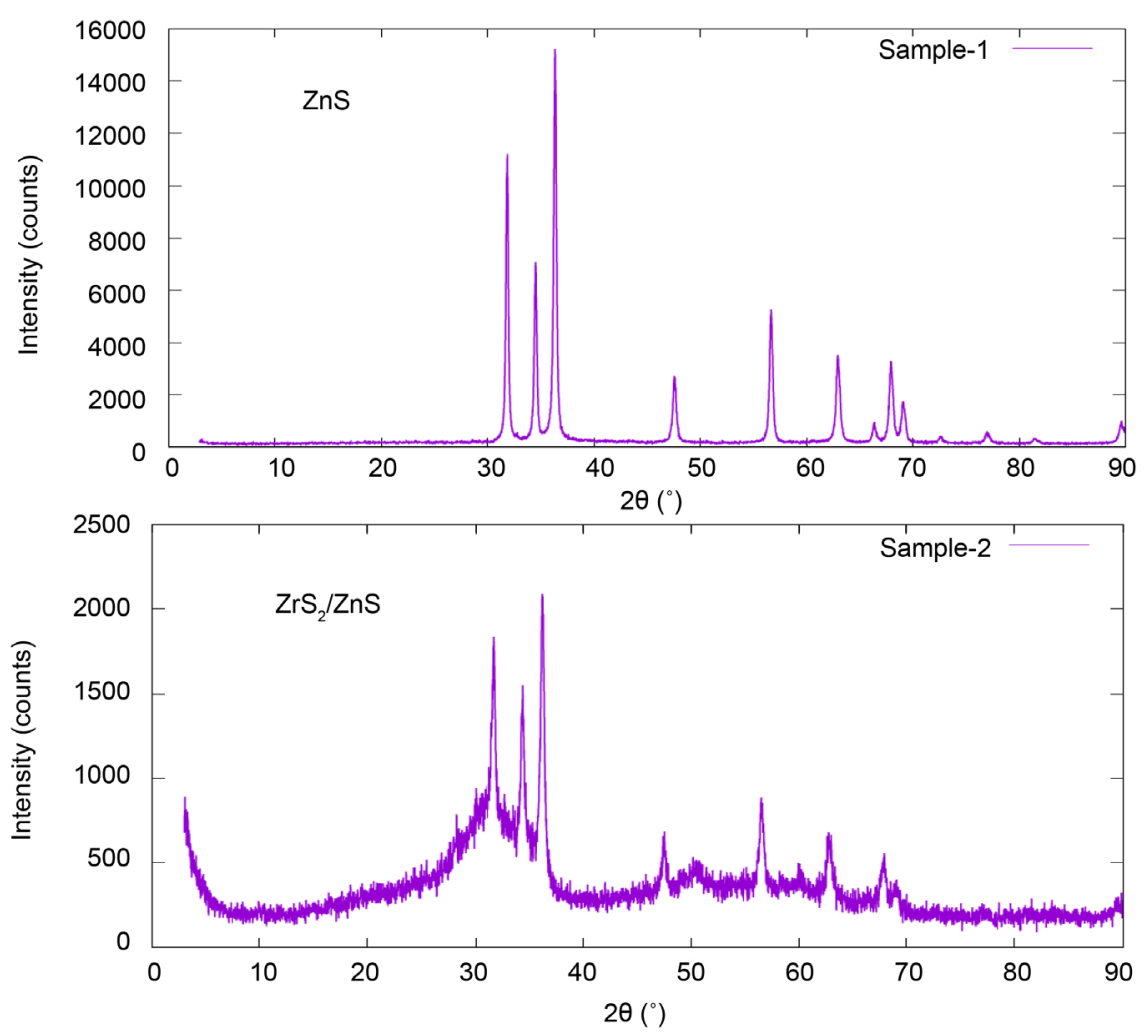

Figure 2. $\mathrm{XRD}$ patterns of $\mathrm{ZnS}$ and $\mathrm{ZrS}_{2} / \mathrm{ZnS}$ nanoparticles.

$\alpha=\beta=\gamma=90^{\circ}$. Accordingly, $\mathrm{ZnS}$ nanoparticles belong to Tetragonal crystal system. Using XRD data, the cell parameters calculated for $\mathrm{ZrS}_{2} / \mathrm{ZnS}$ nanoparticles are found to be $a=b \neq c(a=6.900 \AA, b=6.900 \AA$ and $c=9.806 \AA)$ and $\alpha=\beta=\gamma=90^{\circ}$. Accordingly, $\mathrm{ZrS}_{2} / \mathrm{ZnS}$ nanoparticles belong to Tetragonal crystal system. The average crystallite size was calculated using Williamson-Hall plot [22] and it was found to be $57.2 \mathrm{~nm}$ for $\mathrm{ZnS}$ and $43.8 \mathrm{~nm}$ for $\mathrm{ZrS}_{2} / \mathrm{ZnS}$ nanoparticles. The angle strain is $3.46 \times 10^{-2}$ for $\mathrm{ZnS}$ and $7.59 \times 10^{-4}$ for $\mathrm{ZrS}_{2} / \mathrm{ZnS}$ nanocomposite.

\subsection{Optical Absorption Spectra}

The UV-Visible spectrum of $\mathrm{ZnS}$ and $\mathrm{ZrS}_{2} / \mathrm{ZnS}$ nanoparticles (Figure 3) over the range $200-600 \mathrm{~nm}$ showed that the synthesized nanoparticles are photoactive under UV light radiation. ZnS nanoparticles showed three absorption peaks where as $\mathrm{ZrS}_{2} / \mathrm{ZnS}$ nanoparticles showed two peaks in the UV region. There is no absorption peak in the visible region. The band gaps of the samples are calculated using Tauc's plot [23] [24] and was found to be $2.7 \mathrm{eV}$ for $\mathrm{ZnS}$ and 3.9 $\mathrm{eV}$ for $\mathrm{ZrS}_{2} / \mathrm{ZnS}$ nanoparticles as shown in Figure 4. The obtained band gap value of $\mathrm{ZnS}$ nanoparticle is lower than that of the bulk value of $\mathrm{ZnS}(3.68 \mathrm{eV})$. This blue shift of the band gap of $\mathrm{ZnS}$ nanoparticle occurs due to quantum confinement effect [25]. The band gap of $\mathrm{ZrS}_{2} / \mathrm{ZnS}$ is very much higher than that of $\mathrm{ZnS}$. This supports lower photocatalytic efficiency of $\mathrm{ZrS}_{2} / \mathrm{ZnS}$ nano particles compared to $\mathrm{ZnS}$ nanoparticles. 


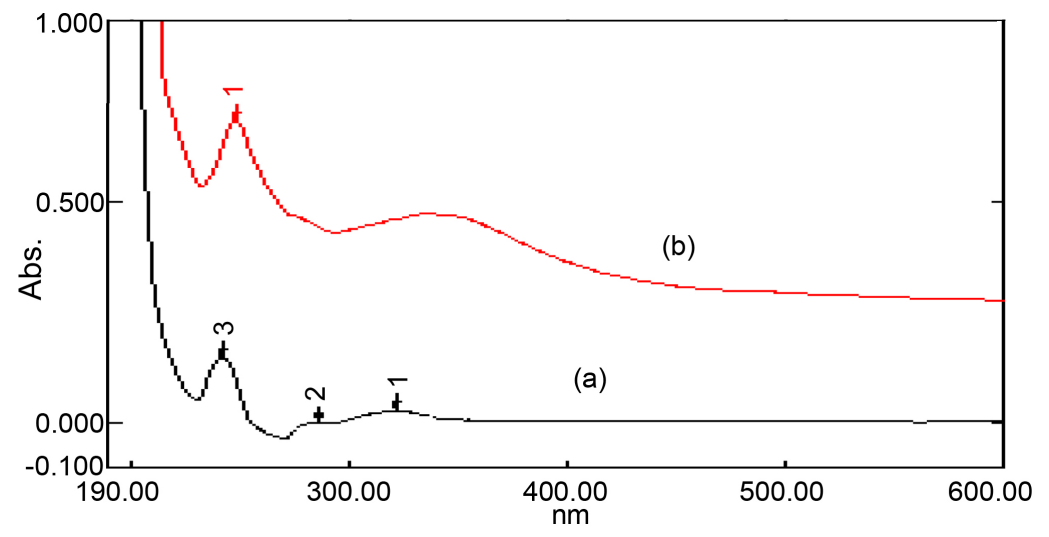

Figure 3. UV-Visible spectra of (a) $\mathrm{ZnS}$ and (b) $\mathrm{ZrS}_{2} / \mathrm{ZnS}$ nanoparticles.
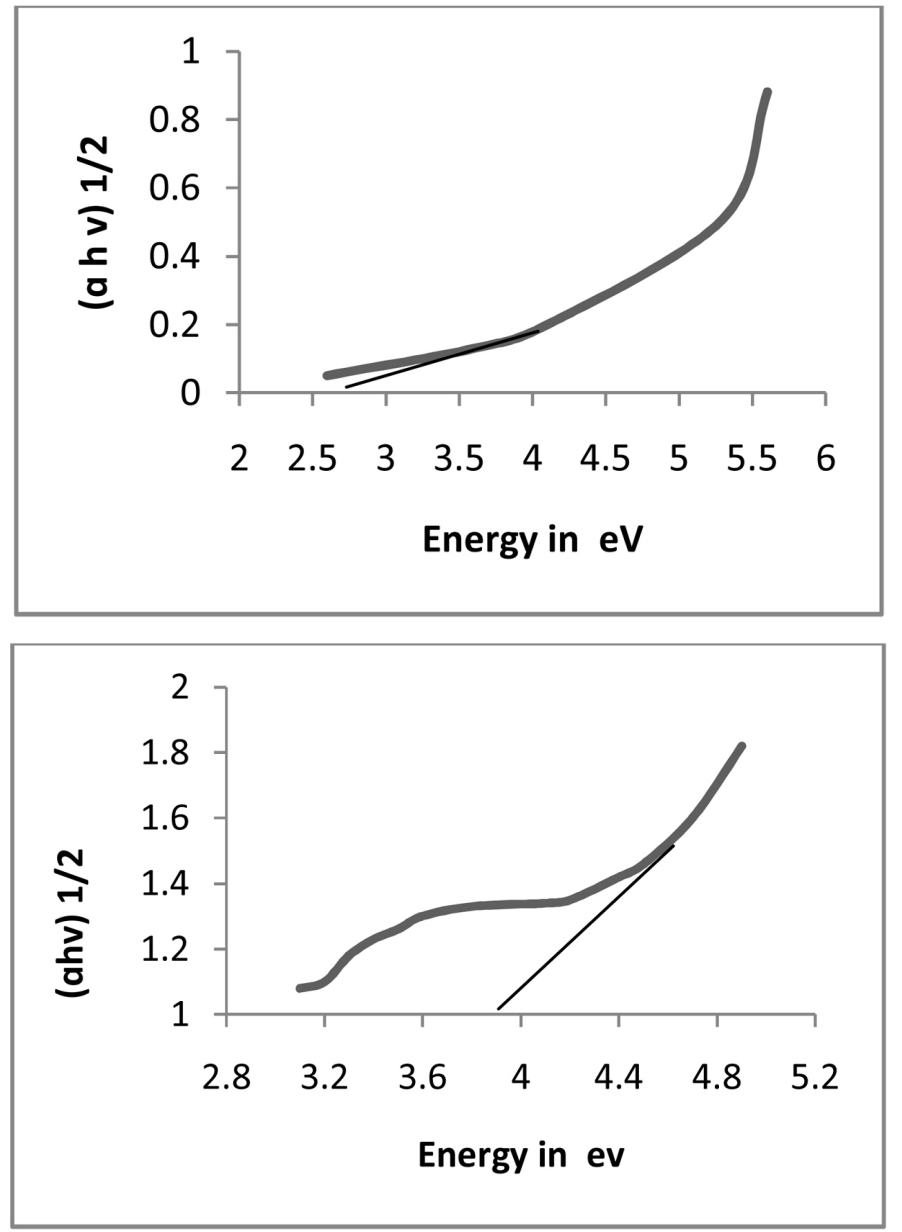

Figure 4. Tauc's plot of $\mathrm{ZnS}$ and $\mathrm{ZrS}_{2} / \mathrm{ZnS}$ nanoparticles.

\subsection{EDX of $\mathrm{ZnS}$ and $\mathrm{ZrS}_{2} / \mathrm{ZnS}$ Nanoparticles}

The EDAX analysis confirmed the presence of Zinc and Sulphur in ZnS and Zirconium, Zinc and Sulphur in $\mathrm{ZrS}_{2} / \mathrm{ZnS}$ nanoparticles (Figure 5 and Figure 6). The surface morphology of $\mathrm{ZnS}$ and $\mathrm{ZrS}_{2} / \mathrm{ZnS}$ nanoparticles was observed by FE-SEM analysis. The SEM images showed that the synthesized nanoparticles consisted of agglomerated particles (Figure 7). 


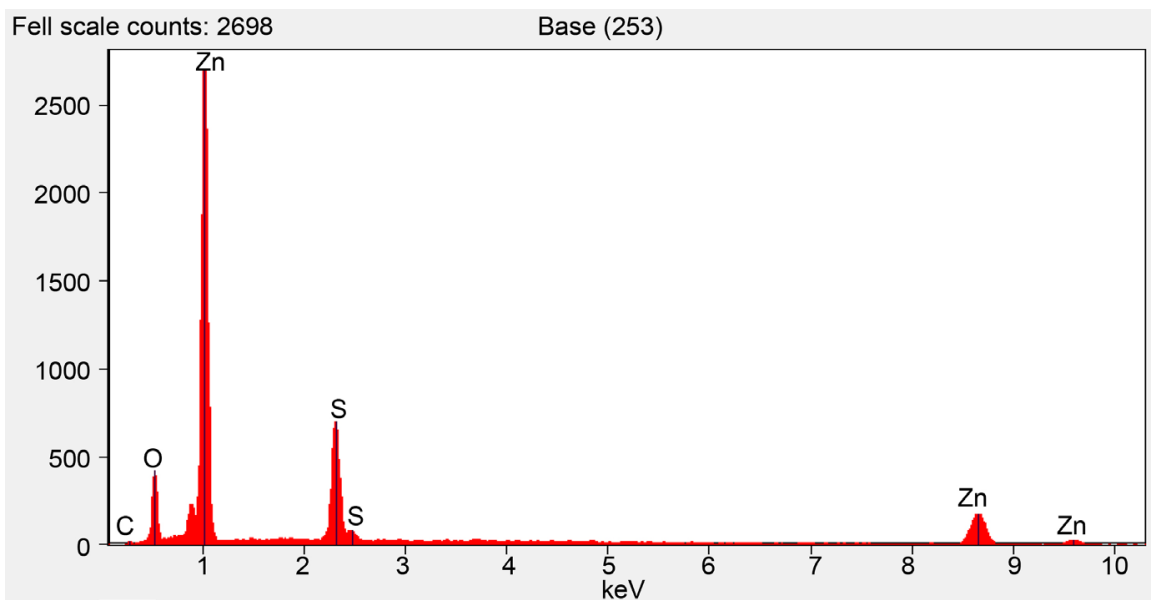

Figure 5. EDAX for $\mathrm{ZnS}$ nanoparticles.

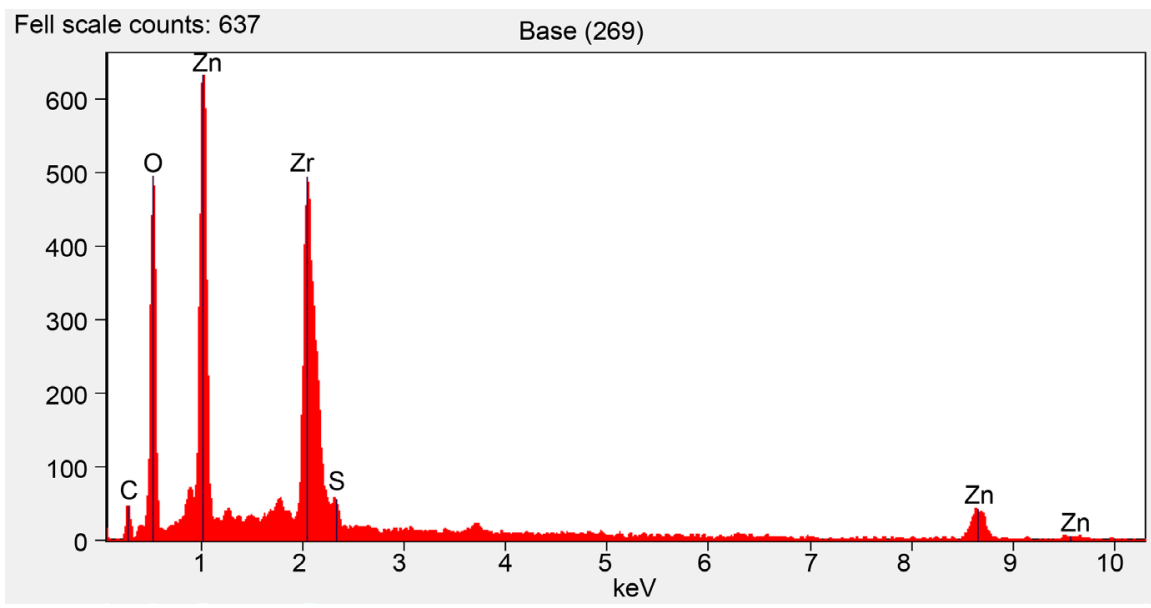

Figure 6. EDAX for $\mathrm{ZrS}_{2} / \mathrm{ZnS}$ nanoparticles.

\subsection{Photo Catalytic Degradation of Indigo Carmine Dye and COD Measurements}

\subsubsection{Effect of Concentration of Dye}

To ensure the optimum dye concentration, photodegradation is carried out with different concentration of Indigo carmine with constant weight of catalyst (Table 1 and Figure 8). As the optimum concentration of catalyst for $\mathrm{ZnS}$ nano particle is $0.02 \mathrm{~g}$, keeping this as standard the same amount of $\mathrm{ZrS}_{2} / \mathrm{ZnS}$ nanopartilce is taken for comparision in the further work. Beyond the optimum dye concentration, as the initial concentration of dye increases, the degradation efficiency reduces. The possible reason is that, as initial concentration of dye is increased, more dye molecules are adsorbed onto the surface of the catalyst. But the adsorbed dye molecules are not degraded immediately because the intensity of the light and the amount of catalyst is constant and also the light penetration is less. Also with increase in dye concentration, the solution becomes more intense coloured and the path length of the photons entering the solution is decreased thereby fewer photons reached the catalyst surface [17]. Hence there will be reduction in the production of ROS species like hydroxyl and superoxide 


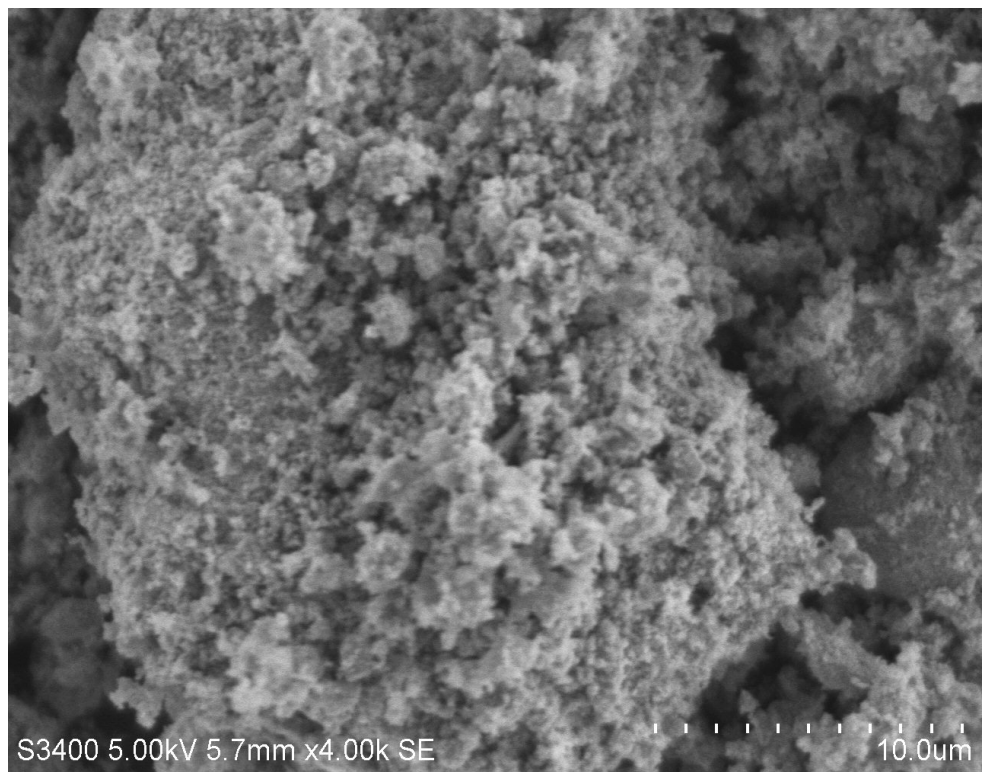

(a)

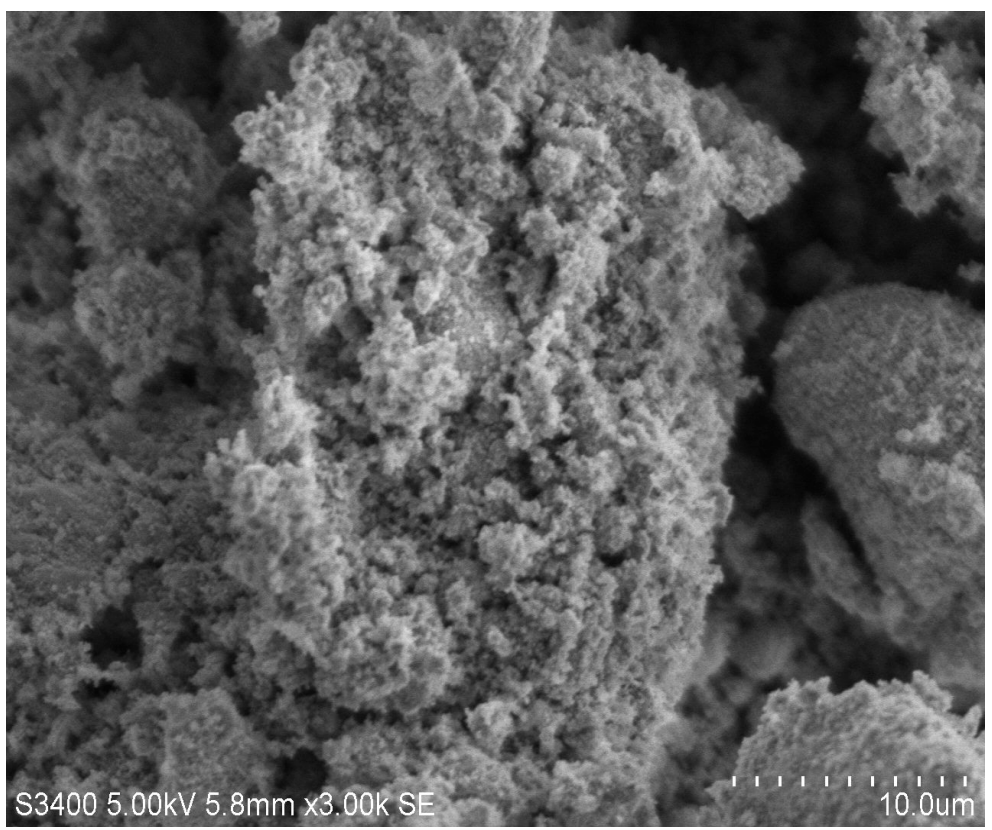

(b)

Figure 7. SEM micrographs of (a) $\mathrm{ZnS}$ and (b) $\mathrm{ZrS}_{2} / \mathrm{ZnS}$ nanoparticles.

radicals [26].

\subsubsection{Effect of Catalyst Loading}

The experiments were performed by taking different amount of catalyst varrying from 0.02 to $0.06 \mathrm{~g}$ in order to study the effect of catalyst loading (Table 2 and Figure 9). Photocatalytic rate initially increases with catalyst loading and then decreases at high values because of light scattering and screening effects [17] [27]. The tendency toward agglomeration also increases at high solid concentration, resulting in a reduction in the surface area available for light absorption and a decrease in photocatalytic degradation rate. The number of active sites in 
Table 1. Effect of concentration of dye on the rate of degradation.

\begin{tabular}{|c|c|c|c|c|c|c|}
\hline \multirow[b]{2}{*}{$\begin{array}{c}\text { Catalyst } \\
0.02 \mathrm{~g}\end{array}$} & \multirow[b]{2}{*}{$\begin{array}{l}\text { Concentratio } \\
\mathrm{n} \text { of dye }(\mathrm{M})\end{array}$} & \multirow[b]{2}{*}{$\mathrm{k} \cdot \sec ^{-1}$} & \multirow{2}{*}{$\begin{array}{l}\text { Time taken for } \\
\text { complete } \\
\text { degradation (min) }\end{array}$} & \multicolumn{2}{|c|}{ COD values in $\mathrm{mg} \cdot \mathrm{L}^{-1}$} & \multirow{2}{*}{$\begin{array}{l}\text { - Degradation } \\
\text { efficiency } \%\end{array}$} \\
\hline & & & & $\begin{array}{c}\text { Before } \\
\text { degradation }\end{array}$ & $\begin{array}{c}\text { After } \\
\text { degradation }\end{array}$ & \\
\hline \multirow{3}{*}{$\begin{array}{c}\text { Zinc } \\
\text { sulphide }\end{array}$} & $0.1 \times 10^{-4}$ & $3.38 \times 10^{-4}$ & 13 & 304 & 48 & 84.21 \\
\hline & $0.2 \times 10^{-4}$ & $5.11 \times 10^{-4}$ & 22 & 352 & 16 & 95.45 \\
\hline & $0.3 \times 10^{-4}$ & $4.47 \times 10^{-4}$ & 82 & 360 & 64 & 82.22 \\
\hline \multirow{3}{*}{$\mathrm{ZrS}_{2} / \mathrm{ZnS}$} & $0.1 \times 10^{-4}$ & $3.41 \times 10^{-5}$ & 150 & 240 & 32 & 86.66 \\
\hline & $0.2 \times 10^{-4}$ & $4.35 \times 10^{-5}$ & 315 & 432 & 48 & 88.88 \\
\hline & $0.3 \times 10^{-4}$ & $6.39 \times 10^{-5}$ & 485 & 320 & 64 & 80.00 \\
\hline
\end{tabular}

Table 2. Effect of catalyst loading on the rate of photo-degradation.

\begin{tabular}{|c|c|c|c|c|c|c|}
\hline \multirow[b]{2}{*}{$\begin{array}{c}\text { Nano } \\
\text { particle }\end{array}$} & \multirow[b]{2}{*}{$\begin{array}{c}\text { Amount of } \\
\text { catalyst } / 20 \mathrm{~m} \\
1\end{array}$} & \multirow[b]{2}{*}{$\mathrm{k} \cdot \sec ^{-1}$} & \multirow[b]{2}{*}{$\begin{array}{c}\text { Time taken for } \\
\text { complete } \\
\text { degradation }(\mathrm{min})\end{array}$} & \multicolumn{2}{|c|}{$\mathrm{COD}$ values in $\mathrm{mg} / \mathrm{L}$} & \multirow[b]{2}{*}{$\begin{array}{l}\text { Degradation } \\
\text { efficiency \% }\end{array}$} \\
\hline & & & & $\begin{array}{c}\text { Before } \\
\text { degradation }\end{array}$ & $\begin{array}{c}\text { After } \\
\text { degradation }\end{array}$ & \\
\hline \multirow[t]{2}{*}{$\begin{array}{c}\text { Commercial } \\
\mathrm{ZnS}\end{array}$} & $0.02 \mathrm{~g}$ & $1.5 \times 10^{-4}$ & 92 & 352 & 288 & 18.18 \\
\hline & $0.02 \mathrm{~g}$ & $14.04 \times 10^{-4}$ & 22 & 352 & 16 & 95.45 \\
\hline \multirow[t]{3}{*}{ Zinc sulphide } & $0.04 \mathrm{~g}$ & $17.13 \times 10^{-4}$ & 22 & 352 & 16 & 95.45 \\
\hline & $0.06 \mathrm{~g}$ & $12.95 \times 10^{-4}$ & 22 & 352 & 16 & 95.45 \\
\hline & $0.02 \mathrm{~g}$ & $4.93 \times 10^{-5}$ & 210 & 192 & 32 & 83.33 \\
\hline \multirow[t]{2}{*}{$\mathrm{ZrS}_{2} / \mathrm{ZnS}$} & $0.04 \mathrm{~g}$ & $7.67 \times 10^{-5}$ & 150 & 192 & 64 & 66.66 \\
\hline & $0.06 \mathrm{~g}$ & $6.39 \times 10^{-5}$ & 130 & 192 & 96 & 50.00 \\
\hline
\end{tabular}

solution will increase with catalyst loading, a point appears to be reached where light penetration is compromised because of excessive particle concentration [28]. A further increase in catalyst loading beyond the optimum will result in non-uniform light intensity distribution, so that the reaction rate would indeed be lower with increased catalyst dosage.

\subsubsection{Effect of Temperature}

Temperature is one of the important factor which effects the rate of photodegradation. Increase of temperature is an indication of slighter increase in the rate of photodegradation as raise in temperature results in number of effective collisions leading to higher rate of reaction. However, the photodegradation efficiency is not much affected (Table 3 and Figure 10).

\subsubsection{Reuse of Catalyst}

The possibility of reusing the photocatalyst was tested to see the cost effectiveness of the method used. After degradation of the dye, the dye solution was kept overnight and then the supernatant liquid was decanted. The photocatalyst was thoroughly washed with double distilled water and then reused for the photodegradation by taking fresh IC dye solution. The reuse sample has shown almost same degradation efficiency compared to the fresh samples (Table 4 and 

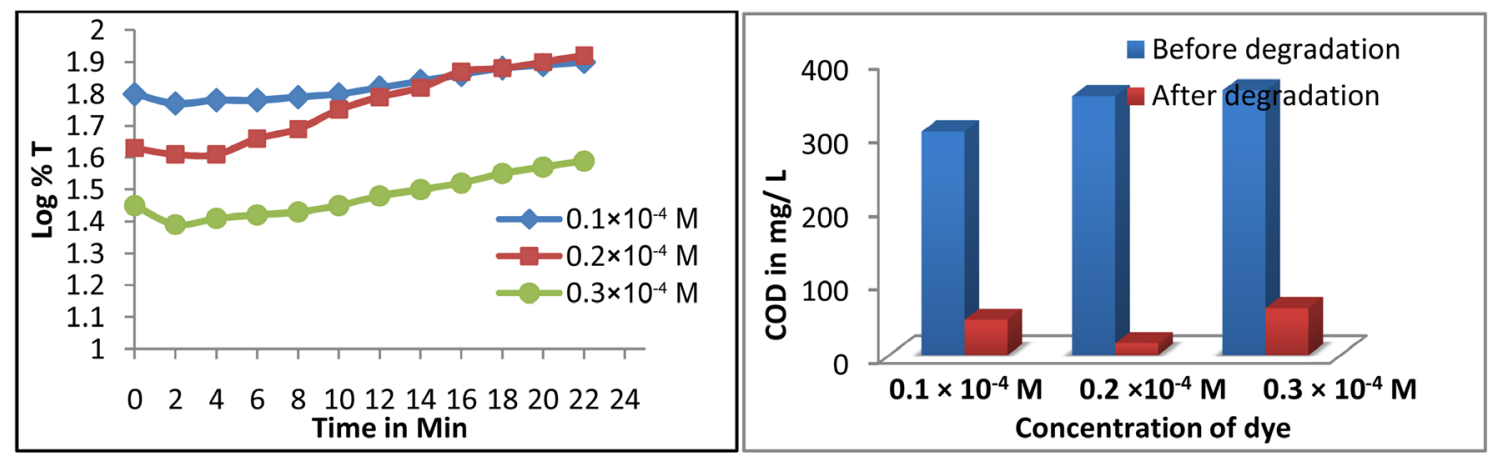

(a)

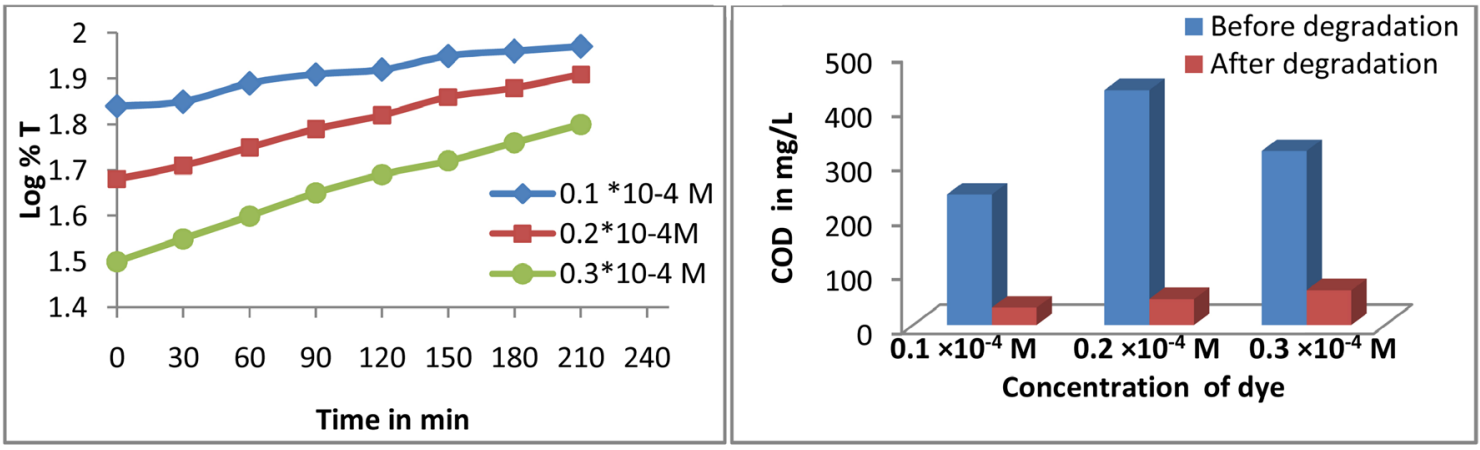

(b)

Figure 8. Plot of log \% T vs. time with respect to different initial concentration of dye and COD values in case of (a) $\mathrm{ZnS}$ and (b) $\mathrm{ZrS}_{2} / \mathrm{ZnS}$ nanoparticles.
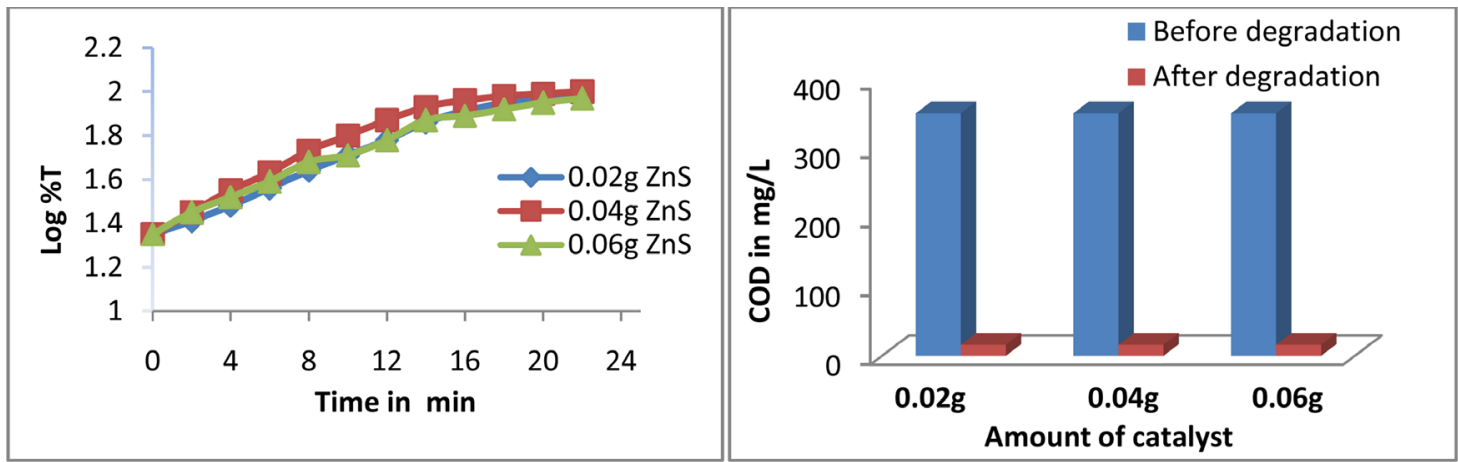

(a)
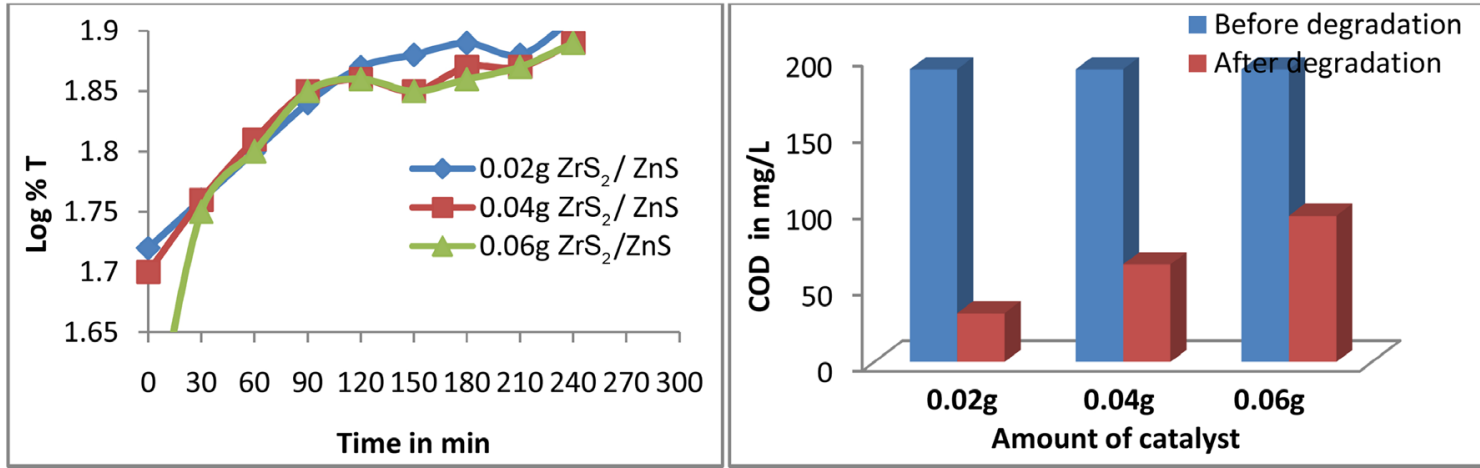

(b)

Figure 9. Plot of $\log \% \mathrm{~T}$ vs. time with respect to catalyst loading and COD values in case of (a) $\mathrm{ZnS}$ and (b) $\mathrm{ZrS}_{2} / \mathrm{ZnS}$ nanoparticles. 

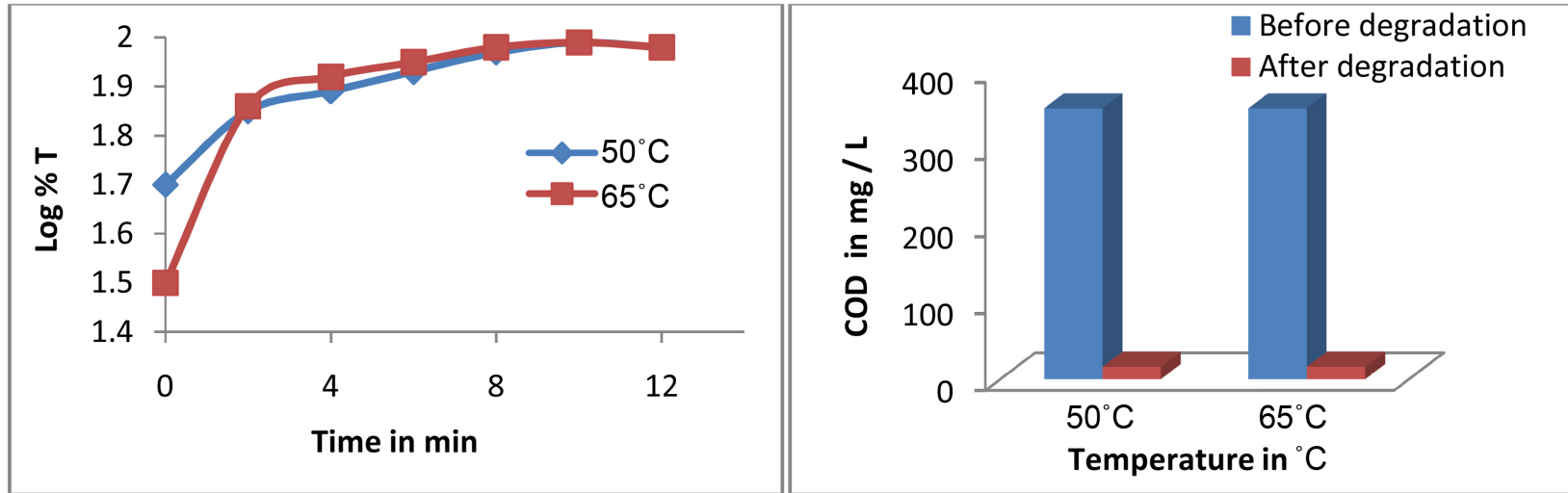

(a)
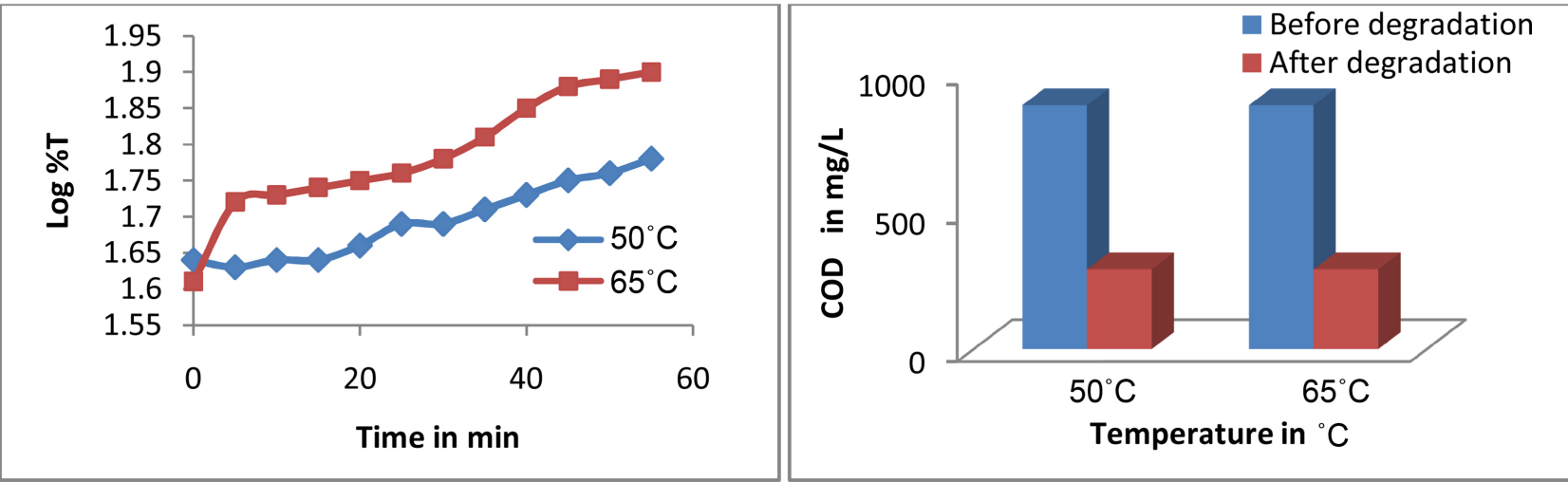

(b)

Figure 10. Plot of $\log \% \mathrm{~T}$ vs. time with respect to temperature in case of (a) $\mathrm{ZnS}$ and (b) $\mathrm{ZrS} / 2 / \mathrm{ZnS}$ nanoparticles.

Table 3. Effect of temperature on degradation of dye.

\begin{tabular}{|c|c|c|c|c|c|c|c|}
\hline \multirow{2}{*}{$\begin{array}{l}\text { Catalyst } \\
0.02 \mathrm{~g}\end{array}$} & \multirow{2}{*}{$\begin{array}{c}\text { Temp } \\
{ }^{\circ} \mathrm{C}\end{array}$} & \multirow{2}{*}{$\begin{array}{l}\text { Concentration } \\
\text { of dye }(\mathrm{M})\end{array}$} & \multirow{2}{*}{$\mathrm{k} \cdot \mathrm{sec}^{-1}$} & \multirow{2}{*}{$\begin{array}{l}\text { Time taken for } \\
\text { complete } \\
\text { degradation } \\
\text { (min) }\end{array}$} & \multicolumn{2}{|c|}{ COD values in $\mathrm{mg} / \mathrm{L}$} & \multirow{2}{*}{$\begin{array}{l}\text { Degradation } \\
\text { efficiency \% }\end{array}$} \\
\hline & & & & & $\begin{array}{c}\text { Before } \\
\text { degradation }\end{array}$ & After degradation & \\
\hline \multirow{2}{*}{$\mathrm{ZnS}$} & 50 & $0.2 \times 10^{-4}$ & $13.5 \times 10^{-4}$ & 10 & 352 & 16 & 95.45 \\
\hline & 65 & $0.2 \times 10^{-4}$ & $15 \times 10^{-4}$ & 12 & 352 & 16 & 95.45 \\
\hline \multirow{2}{*}{$\mathrm{ZrS}_{2} / \mathrm{ZnS}$} & 50 & $0.2 \times 10^{-4}$ & $11.51 \times 10^{-5}$ & 110 & 880 & 288 & 67.27 \\
\hline & 65 & $0.2 \times 10^{-4}$ & $8.25 \times 10^{-5}$ & 90 & 880 & 288 & 67.27 \\
\hline
\end{tabular}

Table 4. Efficiency of catalyst in second use.

\begin{tabular}{|c|c|c|c|c|c|c|}
\hline \multirow{2}{*}{$\begin{array}{l}\text { Catalyst } \\
0.02 \mathrm{~g}\end{array}$} & \multirow{2}{*}{$\begin{array}{c}\text { Concentration of } \\
\text { dye (M) }\end{array}$} & \multirow{2}{*}{$\mathrm{k} \cdot \sec ^{-1}$} & \multirow{2}{*}{$\begin{array}{c}\text { Time taken for } \\
\text { complete } \\
\text { degradation }(\mathrm{min})\end{array}$} & \multicolumn{2}{|c|}{ COD values in $\mathrm{mg} / \mathrm{L}$} & \multirow{2}{*}{$\begin{array}{l}\text { Degradation } \\
\text { efficiency \% }\end{array}$} \\
\hline & & & & $\begin{array}{c}\text { Before } \\
\text { degradation }\end{array}$ & After degradation & \\
\hline $\mathrm{ZnS}$ & $0.2 \times 10^{-4}$ & $1.34 \times 10^{-4}$ & 130 & 352 & 16 & 95.4 \\
\hline $\mathrm{ZrS}_{2} / \mathrm{ZnS}$ & $0.2 \times 10^{-4}$ & $5.29 \times 10^{-5}$ & 290 & 352 & 64 & 81.81 \\
\hline
\end{tabular}

Figure 11), while an obviously decrease in photoactivity was noticed with the reuse cycles [29]. This indicates the nano samples can be regenerated and reused 

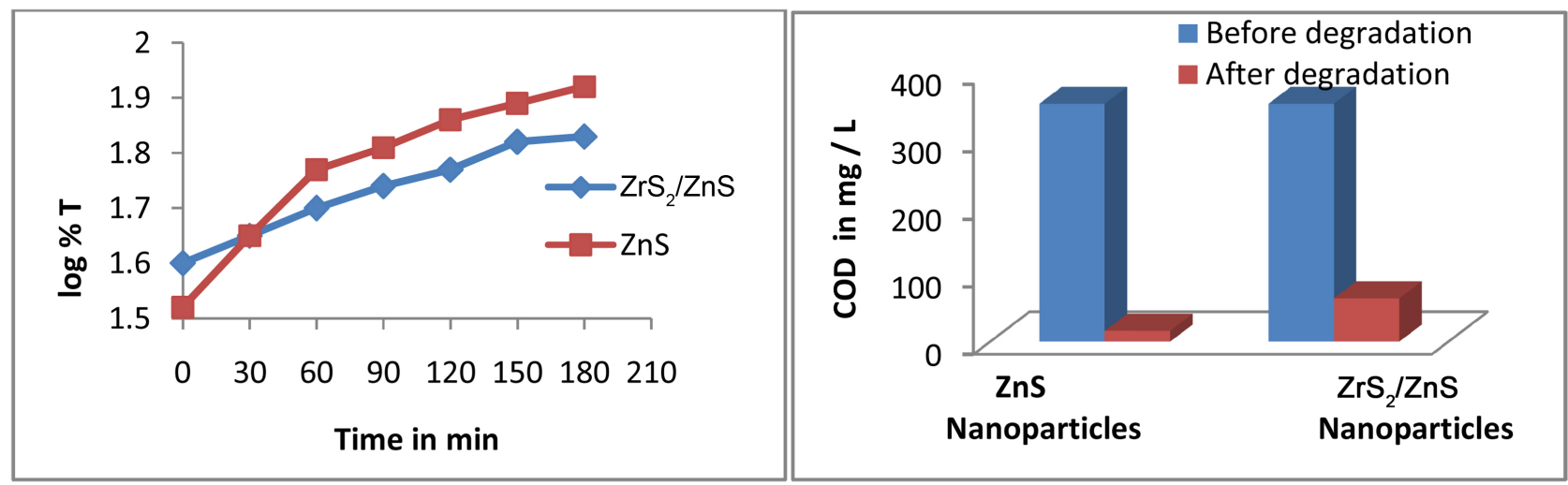

Figure 11. Plot of $\log \% \mathrm{~T}$ vs. time with respect to reuse of catalyst and COD values in case of $\mathrm{ZnS}$ and $\mathrm{ZrS} / \mathrm{ZnS}$ nanoparticles.

with very low or significance change in the efficiency. An obviously decrease in rate of reaction was observed with the second use of catalyst. Reuse cycles might cause the aggregation of photocatalyst and the decrease in specific surface area and the losses of catalyst, resulting in a loss of catalytic activity [30].

\section{Biological Activities}

\subsection{Antibacterial Activity}

\subsubsection{Bacterial Growth Condition}

The Gram negative bioluminescent Photobacterium leiognathi (accession number: KM434234), isolated from coastal area of Goa, were used in this study. Bacteria were grown in nutrient broth (NB) containing $3 \%$ sodium chloride with aeration at $25^{\circ} \mathrm{C}$ for $24 \mathrm{~h} .10 \mu \mathrm{l}$ of the overnight culture was inoculated into 100 $\mathrm{ml}$ of nutrient broth and incubated under same condition until the $\mathrm{OD}_{600}$ reaches 0.5 (approximately 12 hours) as at this OD bacteria were emitting the maximum amount of light.

\subsubsection{Reagents}

$1 \mathrm{mg} / \mathrm{ml}$ stock solution nanoparticle (NPs) was prepared in sterile distilled water. To disperse the NPs, the suspension was sonicated before use. Later NPs dilutions were prepared in sterile broth. As these solutions are later inoculated with an equal amount of bacteria in broth, the dilutions are prepared at concentration twice the desired final concentration.

\subsubsection{Minimum Inhibitory Concentration (MIC) Assay}

Broth microdilution technique has been used to determine the MIC of nanoparticle. For this purpose, two fold serial dilutions of the compound ranging from 500 to $0.4 \mu \mathrm{g} / \mathrm{ml}$ were performed in 96 -well white microtiter plate. Initially 100 $\mu \mathrm{l}$ of bacterial inoculums was placed into the wells of the plate and later each well seeded with $100 \mu \mathrm{l}$ of nanoparticle dilutions. Bacterial luminescent intensity was measured using a luminometer after $6 \mathrm{~h}$ incubation at $25^{\circ} \mathrm{C}$ with $150 \mathrm{rpm}$ shaking. In addition to the NP-treated well, each plate had untreated bacterial culture as control. Sterile broth containing NP and sterile broth also served as blank for the test and control respectively. NP efficacy was calculated from the 
blanks, control and treated luminescence values on a plate.

$$
\text { Percentage of inhibition }=\left[\left(C-B_{1}\right)-\left(T-B_{2}\right) /\left(C-B_{1}\right)\right] * 100
$$

where $B_{1}$ denotes the average luminescence for sterile broth, $B_{2}$ denotes the average luminescence for sterile broth containing NP, $C$ denotes the average luminescence for control and $T$ denotes the average luminescence for treated wells.

\subsubsection{Result and Discussion}

The MIC is defined as the lowest concentration of NPs that inhibits the growth of a microorganism. The percentage of inhibition for $\mathrm{ZnS}$ and $\mathrm{ZrS}_{2} / \mathrm{ZnS}$ has showed in Table 5 and Figure 12. The MIC value for $\mathrm{ZnS}$ and $\mathrm{ZrS}_{2} / \mathrm{ZnS}$ is 500 and $15.6 \mu \mathrm{g} / \mathrm{ml}$ respectively. These results indicate that the $\mathrm{ZrS}_{2} / \mathrm{ZnS}$ has higher antimicrobial activity than zinc sulphide.

\subsection{Antimitotic Activity}

The antimitotic activities of synthesized nanoparticles were determined by onion root tip method. Allium cepa has been used to evaluate the antimitotic activity of synthesized $\mathrm{ZnS}$ and $\mathrm{ZrS}_{2} / \mathrm{ZnS}$ nanoparticles. The results of antimitotic activity are given in Table 6 and the percentage inhibition of cell division by $\mathrm{ZnS}$ and $\mathrm{ZrS}_{2} / \mathrm{ZnS}$ nanoparticles comparative to control is given in Figures 13(a)-(d). Onion roots in $\mathrm{ZnS}$ and $\mathrm{ZrS}_{2} / \mathrm{ZnS}$ of concentration (25, 50 and $75 \mathrm{ppm}$ )

Table 5. Inhibition of bacterial growth at different concentrations of nanoparticles ( $\mu \mathrm{g} /$ $\mathrm{ml})$.

\begin{tabular}{|c|c|c|c|c|c|c|c|c|c|c|c|c|}
\hline \multicolumn{2}{|c|}{$\begin{array}{l}\text { Np Concentration } \\
(\mu \mathrm{g} / \mathrm{ml})\end{array}$} & 500 & 250 & 125 & 62.5 & 31.25 & 15.6 & 7.8 & 3.9 & 1.9 & 0.97 & 0.48 \\
\hline$\%$ of & $\mathrm{ZrS}_{2} / \mathrm{ZnS}$ & 148 & 140 & 130 & 127 & 110 & 100 & 75 & 74 & 72 & 70 & 15 \\
\hline inhibition & $\mathrm{ZnS}$ & 124 & 86 & 69 & 54 & 37 & 35 & 33 & 31 & 20 & 16 & 5 \\
\hline
\end{tabular}

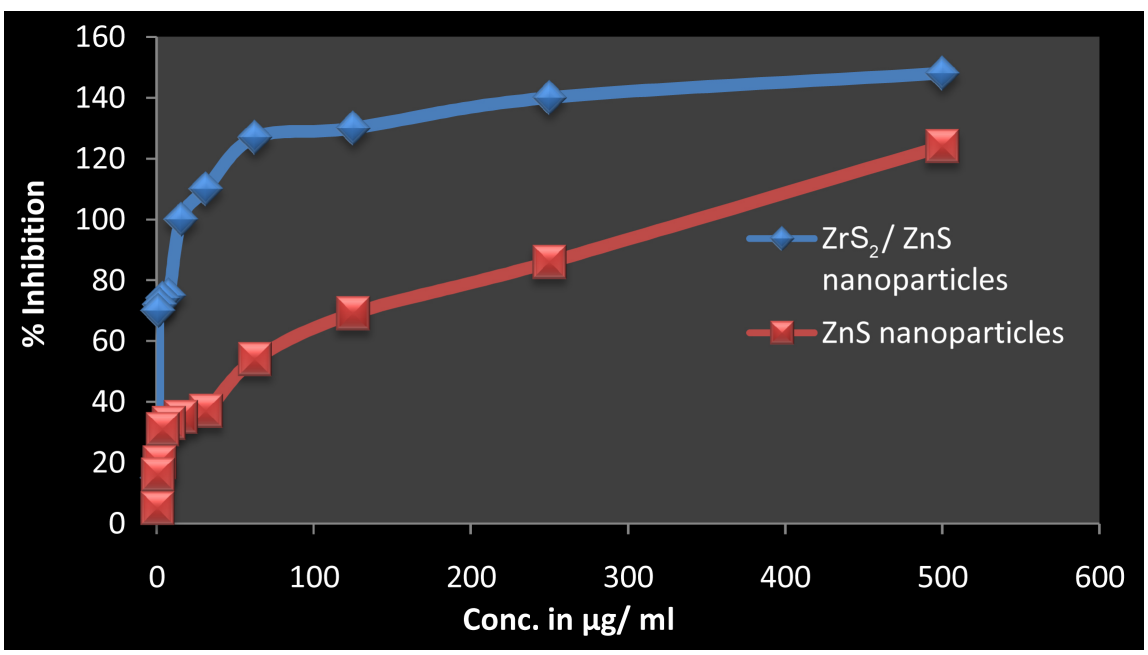

Figure 12. Plot of \% Inhibition vs. Conc. in $\mu \mathrm{g} / \mathrm{ml}$ with respect to $\mathrm{ZnS}$ and $\mathrm{ZrS}_{2} / \mathrm{ZnS} \mathrm{Na}$ noparticles. 
Table 6. Antimitotic activity results of $\mathrm{ZnS}$ and $\mathrm{ZrS}_{2} / \mathrm{ZnS}$ nanoparticles.

\begin{tabular}{cccccccccccc}
\hline \multirow{2}{*}{ Compound } & $\begin{array}{c}\text { Conc. in } \\
\text { ppm }\end{array}$ & \multicolumn{3}{c}{ \% Dividing cells } & \multicolumn{4}{c}{$\begin{array}{c}\text { \% Dividing Cells } \\
\text { compared to control }\end{array}$} & \multicolumn{3}{c}{$\begin{array}{c}\text { \% Inhibition } \\
\text { compared to control }\end{array}$} \\
\cline { 3 - 12 } & & $12 \mathrm{hrs}$ & $18 \mathrm{hrs}$ & $24 \mathrm{hrs}$ & $12 \mathrm{hrs}$ & $18 \mathrm{hrs}$ & $24 \mathrm{hrs}$ & $12 \mathrm{hrs}$ & $18 \mathrm{hrs}$ & $24 \mathrm{hrs}$ \\
\hline Control & SDW & 67.03 & 74.27 & 71.24 & 0.00 & 0.00 & 0.00 & 00.00 & 0.00 & 0.00 \\
$\mathrm{ZnS}$ & 25 & 43.21 & 33.23 & 36.79 & 64.46 & 44.74 & 51.63 & 35.53 & 55.25 & 48.36 \\
& 50 & 42.41 & 30.71 & 33.14 & 63.26 & 41.34 & 46.52 & 36.73 & 58.65 & 53.47 \\
& 75 & 39.81 & 32.13 & 27.21 & 59.39 & 43.25 & 38.19 & 40.60 & 56.74 & 61.80 \\
$\mathrm{ZrS}_{2} / \mathrm{ZnS}$ & 25 & 30.88 & 29.20 & 32.63 & 46.07 & 39.31 & 45.80 & 53.92 & 60.68 & 54.19 \\
& 50 & 27.41 & 30.13 & 33.26 & 40.89 & 40.56 & 46.69 & 59.10 & 59.43 & 53.30 \\
& 75 & 28.58 & 29.71 & 29.11 & 42.63 & 40.00 & 40.86 & 57.36 & 59.99 & 59.13 \\
\hline
\end{tabular}

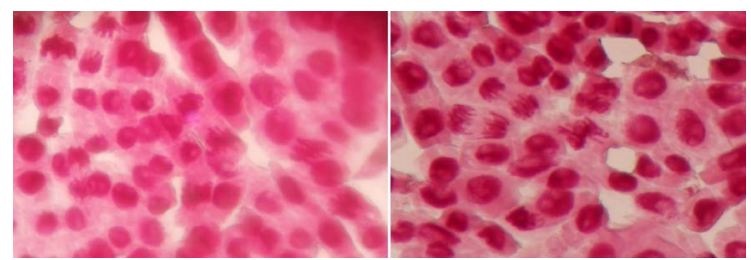

(a)

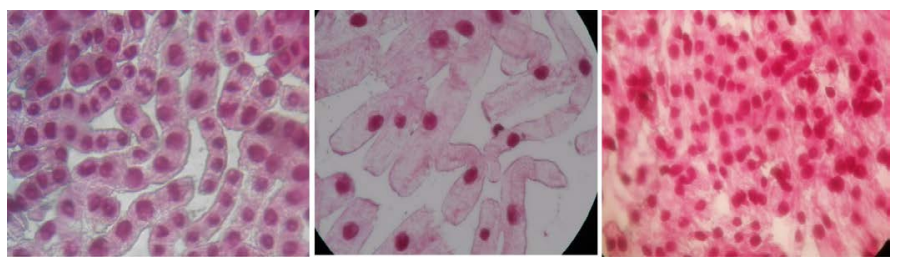

(b)

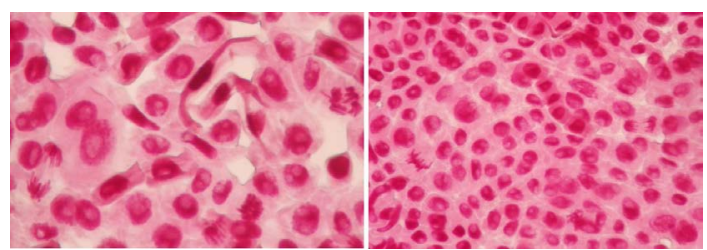

(c)

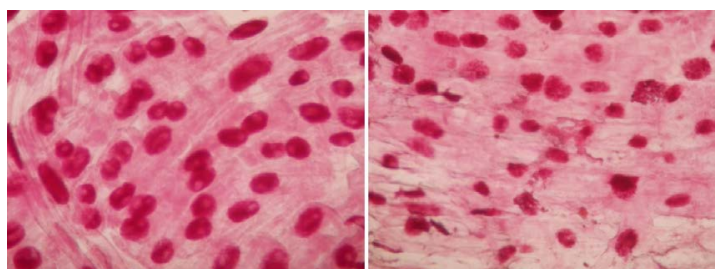

(d)

Figure 13. (a) Various stages of cell divisions seen under $40 \times$ microscopic field with normal cell division stages in control (SDW) treated groups. (b) Cells seen after 12 hours of treatment and observed under A: 40× with less stages of cell divisions, B: seen under oil immersion, there is no any further stages of cell divisions. (c) Cells seen after 18 hours of treatment and observed under A: 40× with very few stages (prophase, late anaphase and early anaphase) of cell divisions, B: seen under $40 \times$ microscopic fields with only metaphase. (d) Cells seen after 24 hours of treatment observed under $40 \times$ microscopic views with very less cell divisions showing chromosomal aberrations, nuclear disintegration and initiation of cellular autolysis with formation of ghost cells. 
at different time duration (12, 18 and $24 \mathrm{hrs}$ ) exhibited changes in chromosomes and shape of the cells with elongated appearance. The change in chromosomes and cellular morphology were achieved in increasing time and concentration. $\mathrm{ZnS}$ and $\mathrm{ZrS}_{2} / \mathrm{ZnS}$ nanoparticles showed good inhibitory effect by inhibiting the cell growth.

From the above observations, the partial-c-mitosis, full-c-mitosis with partial functional spindles and comparatively normal mitotic cells phases were noticed in various cells of the same root tip between 12 - $24 \mathrm{hrs}$ time duration. Therefore, the antimitotic ability of $\mathrm{ZnS}$ and $\mathrm{ZrS}_{2} / \mathrm{ZnS}$ was remarkable in controlling the cell division and acts as potent antimitotic agents.

\section{Conclusion}

In this study, we have reported the synthesis of $\mathrm{ZnS}$ and $\mathrm{ZrS}_{2} / \mathrm{ZnS}$ nanoparticles by novel electrochemical method which is simple, cost effective and ecofriendly method. The photo degradation by these semiconductors offers a green technology for the removal of hazardous compounds present in waste water and industrial effluents. The kinetics of degradation of Indigo carmine has been studied. The complete degradation reaction was confirmed by conducting COD experiment. The synthesized nanoparticles are capable of entering into the Allium cepa cell and bacterial cell, therefore, inhibit the cell growth and hence confirm the biological activity as a potent antimitotic and antimicrobial agents. Moreover, $\mathrm{ZrS}_{2} / \mathrm{ZnS}$ nanoparticles have less photo catalytic activity compared with $\mathrm{ZnS}$ nanoparticles towards photodegradation. The presence of $\mathrm{Zr}$ suppresses the rate of photo-catalytic activity. $\mathrm{ZnS}$ nanoparticles are very good photocatalyst compared with $\mathrm{ZrS}_{2} / \mathrm{ZnS}$ nanocomposite. Hence, $\mathrm{ZrS}_{2} / \mathrm{ZnS}$ nanocomposite can be used to block UV radiation and can be used in the preparation of cosmetics. The degradation efficiency is $\sim 95 \%$ in case of $\mathrm{ZnS}$ where as $83 \%$ in $\mathrm{ZrS}_{2} / \mathrm{ZnS}$ nanocomposites.

\section{Acknowledgements}

This work has been supported by University of Mysore, Mysuru and the Author Uma, H. B. is thankful to UGC, New Delhi for providing financial assistance through BSR meritorious fellowship.

\section{Competing Interests}

Authors have declared that no competing interests exist.

\section{References}

[1] Zhang, L., Wong, K.-H., Chen, Z., Yu, J.C., Zhao, J., Hu, C., Chan, C.Y. and Wong, P.K. (2009) AgBr-Ag-Bi ${ }_{2} W_{6}$ Nanojunction System: A Novel and Efficient Photocatalyst with Double Visible-Light Active Components. Applied Catalysis A: General, 363, 221-229. https://doi.org/10.1016/j.apcata.2009.05.028

[2] Therese, G.H.A. and Kamath, P.V. (2000) Electrochemical Synthesis of Metal Oxides and Hydroxides. Chemistry of Materials, 12, 1195-1204.

https://doi.org/10.1021/cm990447a 
[3] Senapati, U.S., Jha, D.K. and Sarkar, D. (2013) Green Synthesis and Characterization of ZnS Nanoparticles. Research Journal of Physical Sciences, 1, 1-6.

[4] Baishya, U. and Sarkar, D. (2011) ZnS Nanocomposite Formation: Effect of ZnS Source Concentration Ratio. Indian Journal of Pure and Applied Physics, 49, 186189.

[5] Maji, S.K., Mukherjee, N., Mondal, A., Adhikary, B. and Kamakar, B. (2011) Synthesis of Nanocrystalline and Mesoporous Zinc Sulphide from a Single Precursor $\mathrm{Zn}\left(\mathrm{SOCCH}_{3}\right)_{2} \mathrm{Lut}_{2}$ Complex. Journal of Physics and Chemistry of Solids, 72, 784788. https://doi.org/10.1016/j.jpcs.2011.03.011

[6] Pathak, C.S., Mandal, M.K. and Agarwala, V. (2013) Synthesis and Characterization of Zinc Sulphide Nanoparticles Prepared by Mechanochemical Route. Superlattices and Microstructues, 58, 135-143. https://doi.org/10.1016/j.spmi.2013.03.011

[7] Hoa, T.T.Q., Vu, L.V., Canh, T.D. and Long, N.N. (2009) Preparation of ZnS Nanoparticles by Hydrothermal Method. Journal of Physics. Conference Series, 187, Article ID: 012081.

[8] Tan, W.B., Huang, N. and Zhang, Y. (2007) Ultrafine Biocompatible Chitosan Nanoparticles Encapsulating Multi-Coloured Quantum Dots for Bioapplications. Journal of Colloid and Interface Science, 310, 464-470. https://doi.org/10.1016/j.jcis.2007.01.083

[9] Grobelsek, I., Rabung, B., Quilitz, M. and Veith, M. (2011) Electrochemical Synthesis of Nanocrystalline Zinc Oxide and Phase Transformations of Zinc Hydroxides. Journal of Nanoparticle Research, 13, 5103-5119. https://doi.org/10.1007/s11051-011-0490-0

[10] Han, W.-K., Choi, J.-W., Hwang, G.-H., Hong, S.-J., Lee, J.-S. and Kang, S.-G. (2006) Fabrication of $\mathrm{Cu}$ Nano Particles by Direct Electrochemical Reduction from CuO Nano Particles. Applied Surface Science, 252, 2832-2838. https://doi.org/10.1016/j.apsusc.2005.04.049

[11] Rodríguez-Sánchez, L., Blanco, M.C. and López-Quintela, M.A. (2000) Electrochemical Synthesis of Silver Nanoparticles. The Journal of Physical Chemistry B, 104, 9683-9688. https://doi.org/10.1021/jp001761r

[12] Lide, D.R. (2007-2008) “Zirconium”, CRC Handbook of Chemistry and Physics. CRC Press, New York, 42.

[13] Perk, L. (2009) The Future of Immune-PET in Drug Development Zirconium-89 and Iodine-124 as Key Factors in Molecular Imaging. Wayback Machine, Amsterdam.

[14] Ingelfinger, J.R. (2015) A New Era for the Treatment of Hyperkalemia? New England Journal of Medicine, 372, 275-277. https://doi.org/10.1056/NEJMe1414112

[15] Vázquez-Cuchillo, O., Gómez, R., Cruz-López, A., Torres-Martínez, L.M., Zanella, R., Alejandre Sandoval, F.J. and Del Ángel-Sánchez, K. (2013) Improving Water Splitting Using $\mathrm{RuO}_{2}-\mathrm{Zr} / \mathrm{Na}_{2} \mathrm{Ti}_{6} \mathrm{O}_{13}$ as a Photocatalyst. Journal of Photochemistry and Photobiology A: Chemistry, 266, 6-11.

[16] Coudray, C., Rachidi, S. and Favier, A. (1993) Effect of Zinc on Superoxide-Dependent Hydroxyl Radical Production in Vitro. Biological Trace Element Research, 38, 273-287.

[17] Subramani, A.K., Byrappa, K., Ananda, S., Lokanatha Rai, K.M., Ranganathaiah, C. and Yoshimura, M. (2007) Photocatalytic Degradation of Indigo Carmine Dye Using $\mathrm{TiO}_{2}$ Impregnated Activated Carbon. Bulletin of Materials Science, 30, 37-41.

[18] Lakshmi, G.C., Ananda, S., Somashekar, R. and Ranganathaiah, C. (2012) Synthesis of $\mathrm{ZnO} / \mathrm{ZrO}_{2}$ Nano Composites by Electrochemical Method and Its Application for 
Photocatalytic Degradation of Fast Green FCF Dye and Paper Dyeing and Printing Press Effluents. International Journal of Advanced Materials Sciences, 3, 221-237.

[19] Byrappa, K., Subramani, A.K., Ananda, S., Rai, K.M.L., Dinesh, R. and Yoshimura, M. (2006) Photocatalytic Degradation of Rhodamine B Dye Using Hydrothermally Synthesized ZnO. Bulletin of Materials Science, 29, 433-438. https://doi.org/10.1007/BF02914073

[20] Neelakandeswaria, N., Sangamia, G., Dharmaraja, N., Taekb, N.K. and Kimb, H.Y. (2011) Spectroscopic Investigations on the Photodegradation of Toluidine Blue Dye Using Cadmium Sulphide Nanoparticles Prepared by a Novel Method. Spectrochimica Acta Part A, 78, 1592-1598.

[21] Xue, Y., Luan, Q., Yang, D., Yao, X. and Zhou, K. (2011) Direct Evidence for Hydroxyl Radical Scavenging Activity of Cerium Oxide Nanoparticles. The Journal of Physical Chemistry, 115, 4433-4438.

[22] Mohamed, S.H. (2010) Photocatalytic, Optical and Electrical Properties of CopperDoped Zinc Sulfide Thin Films. Journal of Physics D: Applied Physics, 43, Article ID: 035406. https://doi.org/10.1088/0022-3727/43/3/035406

[23] Li, C. and Song, G. (2009) Photocatalytic Degradation of Organic Pollutants and Detection of Chemical Oxygen Demand by Fluorescence Methods. Sensors and Actuators B: Chemical, 137, 432-436. https://doi.org/10.1016/j.snb.2009.01.055

[24] Lakshmi, G.C., Ananda, S., Somashekar, R. and Ranganathiah, C. (2012) Synthesis, Characterization and Photocatalytic Activity of $\mathrm{ZnO}$ : Sn Nanocomposites. International Journal of Advances Science and Technology, 5, 54-64.

[25] Van Dijken, A., Janssen, A.H., Smitsmans, M.H., Vanmaekelbergh, D. and Meijerink, A. (1998) Size-Selective Photoetching of Nanocrystalline Semiconductor Particles. Chemistry of Materials, 10, 3513-3522. https://doi.org/10.1021/cm980715p

[26] Li, W., Li, D., Wang, J., Shao, Y., You, J. and Teng, F. (2013) Exploration of the Active Species in the Photocatalytic Degradation of Methyl Orange under UV Light Irradiation. Journal of Molecular Catalysis A: Chemical, 380, 10-17. https://doi.org/10.1016/j.molcata.2013.09.001

[27] Li, H., Hong, W., Cui, Y., Jia, Q. and Fan, S. (2013) High Photocatalytic Activity of $\mathrm{C}-\mathrm{ZnSn}(\mathrm{OH})_{6}$ Catalysts Prepared by Hydrothermal Method. Journal of Molecular Catalysis A: Chemical, 378, 164-173. https://doi.org/10.1016/j.molcata.2013.06.012

[28] Nešić, J., Manojlović, D.D., Anđelković, I., Dojčinović, B.P., Vulić, P.J., Krstić, J. and Roglić, G.M. (2013) Preparation, Characterization and Photocatalytic Activity of Lanthanum and Vanadium Co-Doped Mesoporous $\mathrm{TiO}_{2}$ for Azo-Dye Degradation. Journal of Molecular Catalysis A: Chemical, 378, 67-75.

[29] Nawawi, W.I. and Nawi, M.A. (2014) Carbon Coated Nitrogen Doped P25 for the Photocatalytic Removal of Organic Pollutants under Solar and Low Energy Visible Light Irradiations. Journal of Molecular Catalysis A: Chemical, 383-384, 83-93. https://doi.org/10.1016/j.molcata.2013.11.030

[30] Sun, W.-J., Li, J., Mele, G., Zhang, Z.-Q. and Zhang, F.-X. (2013) Enhanced Photocatalytic Degradation of Rhodamine B by Surface Modification of $\mathrm{ZnO}$ with Copper (II) Porphyrin under Both UV-Vis and Visible Light Irradiation. Journal of Molecular Catalysis A: Chemical, 366, 84-91. 
Submit or recommend next manuscript to SCIRP and we will provide best service for you:

Accepting pre-submission inquiries through Email, Facebook, LinkedIn, Twitter, etc. A wide selection of journals (inclusive of 9 subjects, more than 200 journals)

Providing 24-hour high-quality service

User-friendly online submission system

Fair and swift peer-review system

Efficient typesetting and proofreading procedure

Display of the result of downloads and visits, as well as the number of cited articles Maximum dissemination of your research work

Submit your manuscript at: http://papersubmission.scirp.org/

Or contact mrc@scirp.org 